Tarbawy : Jurnal Pendidikan Islam

ISSN : 2407-4462 (Cetak), 2614-5812 (Elektronik)

Vol. 7, No. 1, 2020, Hal. 42-46

DOI: https://doi.org/10.32923/tarbawy.v7i1.1180

\title{
Penerapan Pola Pembelajaran Di SD IT Al Bina Pangkalpinang
}

\author{
Fazrul Sandi Purnomo ${ }^{1}$, Sasih Karnita Arafatun ${ }^{2}$ \\ ${ }^{1}$ IAIN Syaikh Abdurrahman Siddik Bangka Belitung \\ ${ }^{2}$ STKIP Muhammadiyah Bangka Belitung
}

\begin{tabular}{l}
\hline \hline Info Artikel : \\
\hline Diterima 1 April 2020 \\
Direvisi 18 April 2020 \\
Dipublikasikan 27 April 2020
\end{tabular}

\author{
Kata Kunci: \\ Pola Pembelajaran \\ Peserta Didik \\ Sekolah Dasar
}

\begin{abstract}
ABSTRAK
Pola pembelajaran yang diterapkan di sekolah menjadi suatu yang penting dan sangat berpengaruh terhadap perkembangan peserta didik karena tujuan dari sekolah adalah mempersiapkan peserta didik sehingga nanti dapat bersaing dikehidupan sosial. Tugas untuk membentuk peserta didik ini bukan perkara yang mudah bagi sekolah. Banyak aspek yang perlu diperhatikan sehingga peserta didik dapat belajar, memperoleh pengetahuan dan pengalaman dengan baik. Di Pangkalpinang, banyak sekolah yang bisa dijadikan contoh dalam penerapan pola pembelajaran, namun dalam tulisan ini penulis memilih Sekolah Dasar Islam Terpadu Al Bina Pangkalpinang. Sekolah Dasar Islam Terpadu Al Bina Pangkalpinang menjadi salah satu rujukan para orang tua untuk menyekolahkan anaknya. Hal ini menandakan bahwa sekolah ini memiliki pola pembelajaran yang baik dan mampu membuat peserta didik belajar serta memperoleh pengetahuan dan pengalaman. Metode kualitatif digunakan guna mendapatkan informasi secara mendalam mengenai pola pembelajaran yang dilaksanakan terhadap peserta didik di Sekolah Dasar Islam Terpadu Al Bina Pangkalpinang.
\end{abstract}

\begin{abstract}
Learning patterns applied in schools become an important and very influential on the development of students because the purpose of the school is to prepare students so that later they can compete in social life. The task of forming learners is not an easy matter for schools. Many aspects need to be considered so that students can learn, gain knowledge and experience well. In Pangkalpinang, many schools can be used as examples in the application of learning patterns, but in this paper the author chose the Al Bina Integrated Islamic Elementary School Pangkalpinang. The Al Bina Integrated Islamic Elementary School Pangkalpinang has become a reference for parents to send their children to school. This indicates that this school has a good learning pattern and is able to make students learn and gain knowledge and experience. Qualitative methods are used to get in-depth information about learning patterns implemented towards students in the Al Bina Integrated Islamic Elementary School Pangkalpinang.
\end{abstract}

\section{Koresponden:}

Fazrul Sandi Purnomo,

Email: fazrulsandi.p@gmail.com

\section{Pendahuluan}

Pada zaman sekarang pendidikan menjadi hal yang sangat dibutuhkan. Peserta didik perlu menerima pengetahuan dan pengalaman selain dari yang telah didapatkan di rumah bersama orang tuanya. Peserta didik adalah orang yang belum dewasa dan memiliki sejumlah potensi yang masih perlu dikembangkan (Danim, 2010). Berdasarkan hal itu muncul kesadaran mengenai kurangnya waktu orang tua untuk memberikan pendidikan terhadap anaknya secara pribadi sehingga berpikir untuk memasukkan anaknya ke sekolah-sekolah yang memiliki kualitas terbaik. Banyak sekolah yang dipertimbangkan oleh para orang tua. Diantara sekolah - sekolah yang ada khususnya di Pangkalpinang terdapat beberapa sekolah yang menjadi rujukan para orang tua. Meskipun biaya pendidikan yang diberikan di atas rata-rata biaya sekolah biasanya, namun tidak menjadi halangan para orang tua untuk menyekolahkan anaknya disana. Salah satunya adalah Sekolah Dasar Islam Terpadu AL Bina Pangkalpinang. Sekolah ini merupakan salah satu sekolah favorit di Pangkalpinang. Fasilitas di sekolah ini memang tergolong baik, namun penulis beranggapan fasilitas yang baik saja tidak akan mampu memberikan pengetahuan dan pengalaman belajar yang baik tanpa didukung pola pembelajaran yang baik pula. Peserta didik merupakan manusia yang memiliki banyak kebutuhan karena terus tumbuh dan berkembang untuk mencapai kedewasaan. Segala usaha dilakukan dalam proses pendidikan untuk mengisi pertumbuhan dan perkembangan tersebut. Salah satu caranya adalah dengan menggunakan pola pembelajaran yang mampu meningkatkan peserta didik secara maksimal. Penulis 
bertujuan untuk mengetahui pola pembelajaran yang dilaksanakan oleh sekolah khususnya oleh para guru Sekolah Dasar Islam Terpadu Al Bina Pangkalpinang yang merupakan salah satu sekolah favorit dan menjadi pilihan para orang tua di Pangkalpinang.

Pola menurut (Nasional, 2015) adalah cara kerja dan pembelajaran menurut Corey (Normawati, 2016) adalah suatu proses dimana lingkungan seseorang secara disengaja dikelola untuk memungkinkan ia turut serta dalam tingkah laku tertentu dalam kondisi-kondisi khusus atau menghasilkan respons terhadap situasi tertentu, pembelajaran merupakan subset khusus dari pendidikan. Sehingga dapat disimpulkan bahwa pola pembelajaran adalan cara kerja yang dilakukan guru untuk mengelola peserta didik sehingga memiliki kemampuan dalam memecahkan permasalahan atau mampu merespon sesuatu yang terjadi dalam situasi tertentu. Berdasarkan hal tersebut dapat diketahui pentingnya kedudukan suatu pola pembelajaran yang diberlakukan di sekolah terhadap peserta didik. Dengan pola yang tepat, peserta didik yang dihasilkan pun akan berkualitas dari segi kemampuan kognitif, afektif, dan psikomotorik.

Pentingnya penulis membuat tulisan ini adalah agar mengetahui keefektifan pola pembelajaran yang dilakukan terhadap peserta didik di Sekolah Dasar Islam Terpadu Al Bina Pangkalpinang. Sekolah dasar ini telah mampu memberikan penilaian baik di mata orang tua peserta didik sehingga menyekolahkan anaknya di sekolah tersebut. Penilaian baik itu tidak datang dengan sendirinya. Hal ini yang membuat penulis menjadi tertarik, ingin mengetahui perlakuan yang diimplementasikan oleh sekolah yang dianggap favorit terutama dari segi pola pembelajaran. Akan tetapi, anggapan seperti ini saja tidak cukup membuktikan hipotesis dari penulis sehingga perlunya dilakukan observasi langsung ke lapangan guna mendapatkan data empiris.

Pola pembelajaran pada Sekolah Dasar Islam Terpadu Al Bina Pangkalpinang berpusat pada kebutuhan peserta didik. Untuk menemukan kebutuhan yang diperlukan oleh peserta didik sebagai pusat yang akan dikembangkan, guru tidak hanya terpaku pada peserta didik itu sendiri, tapi juga pada orang tuanya. Dengan memperoleh data sebanyak-banyaknya maka dapat disusun proses pembelajaran yang baik. Selain itu, temuan ini juga dapat dikembangkan ke penelitian yang lebih besar yang akan berpengaruh pada peningkatan pendidikan di Indonesia khususnya di Pangkalpinang. Bayangkan bila seluruh sekolah memiliki pola pembelajaran yang semakin meningkat, baik itu dengan cara meniru ataupun meniru dengan modifikasi, bukan tidak mungkin pendidikan di Indonesia khususnya di Pangkapinang akan berkembang dengan pesat.

Dengan demikian pola pembelajaran adalah suatu hal yang memang sangat penting untuk meningkatkan perkembangan peserta didik dalam hal kognitif, afektif dan psikomotorik. Perkembangan yang terjadi karena pola pembelajaran yang baik akan memberi pengalaman dan pengetahuan yang dibutuhkan peserta didik untuk menghadapi ataupun merespon suatu keadaan tertentu. Hal ini secara tidak langsung akan membantu masa depan dari peserta didik agar tidak tertelan oleh perkembangan zaman yang semakin cepat. Pola pembelajaran yang baik terlahir dari guru yang benar-benar memperhatikan peserta didiknya. Guru melakukan berbagai cara untuk mendapatkan informasi guna mengembangkan proses pembelajaran di kelas.

\section{Metode}

Penelitian ini dilakukan di Pangkalpinang dan bertempat di Sekolah Dasar Islam Terpadu Al Bina Pangkalpinang. Adapun pertimbangan memilih lokasi ini adalah bahwa sekolah tersebut merupakan salah satu sekolah unggulan atau favorit di Pangkalpinang yang telah diakui oleh orang tua peserta didik. Metode yang digunakan dalam penelitian ini adalah deskriptif kualitatif. Penelitian kualitatif sebagai metode penelitian yang berlandaskan pada filsafat post positivisme, digunakan untuk meneliti pada kondisi objek alamiah, dimana peneliti adalah sebagai instrumen kunci, teknik pengumpulan data dengan triangulasi, analisis data bersifat induktif atau kualitatif, dan hasil penelitian kualitatif lebih menekankan makna daripada generalisasi (Sugiyono, 2015). Penelitian deskriptif kualitatif ditujukan untuk mendeskripsikan dan menggambarkan fenomena -fenomena yang ada, baik bersifat alamiah maupun rekayasa manusia, yang lebih memperhatikan mengenai karakteristik, kualitas, keterkaitan antar kegiatan (Sukmadinata, n.d.). Selain itu, Penelitian deskriptif tidak memberikan perlakuan, manipulasi atau pengubahan pada variabel variabel yang diteliti, melainkan menggambarkan suatu kondisi yang apa adanya. Satu-satunya perlakuan yang diberikan hanyalah penelitian itu sendiri, yang dilakukan melalui observasi, wawancara, dan dokumen dengan menggunakan metode wawancara dan pengamatan langsung. 


\section{Hasil dan Pembahasan}

Pola pembelajaran yang dilakukan di SD IT Al Bina mengintegrasikan nilai-nilai keislaman dalam bagan kurikulum secara umum, dengan konsep bahwa sumber ilmu itu Alquran. Pernyataan itu sesuai dengan pernyataan dari Qutub dan Humaniora, Ilmu pengetahuan adalah merupakan salah satu isi pokok kandungan kitab suci Alquran. Bahkan kata 'ilm itu sendiri disebut dalam Alquran sebanyak 105 kali, tetapi dengan kata jadiannya ia disebut lebih dari 744 kali menurut Rahardjo dalam (Qutub, 2011).

Dalam pelaksanaan konsep ini sekolah full day ini setiap pagi seluruh kelas melakukan majlis pagi dengan kegiatan sholat dhuha bersama, hafalan hadist, hafalan Alquran sesuai kelasnya, Bahasa Inggris dan Bahasa Arab. Setelah majlis pagi selesai, baru masuk pelajaran umum yakni tematik karena sekolah ini telah memberlakukan Kurikulum 2013. Setelah sholat Dhuhur pembelajaran dilanjutkan kembali. Pada pukul 14.00 WIB baru dimulai kegiatan eskul seperti karate, pramuka, tahfidul quran untuk kelas tinggi, dan kelas rendah diajarkan life skill kecakapan mendasar seperti membuat es buah, melipat baju, menyiang ikan (membersihkan) dll. Sementara eskul pilihannya dokter kecil, dai kecil, nasyid, futsal dan memanah. Sejalan dengan pernyataan Mawardi dalam (Marganingsih, Pelipa, \& Erwin, 2019). Kecakapan Hidup (Life Skills) sebagai kontinum pengetahuan dan kemampuan yang diperlukan oleh seseorang untuk berfungsi secara independen dalam kehidupan (Mawardi, 2012). Hari sabtu guru tetap masuk tapi setengah hari untuk saling membekali dalam memberikan informasi mengenai peserta didik .

Pengamatan yang dilakukan saat pembelajaran di kelas 1, guru kelas Indawati Trisakti membimbing siswa membaca secara bergantian dilanjutkan praktik menempel gambar dengan alat-alat yang disediakan guru. Dalam berbagai kesempatan akan diselingi hadis-hadis guna menanamkan nilai bagi peserta didik. Adapun persiapan guru sebelum mengajar membuat silabus, RPP, serta menyiapkan media sesuai dengan pelajarannya. Demikian pentingnya persiapan dan perencanaan pembelajaran ini, sehingga bila seorang guru tidak menguasai cara-cara persiapan dan perencanaan pembelajaran yang baik, sudah dapat dipastikan bahwa pembelajaran yang dilakukan tidak akan berhasil secara optimal. Membimbing peserta didik yang duduk di kelas 1, di awal pembelajaran, masih banyak peserta didik yang terkejut karena waktu sekolah dari pagi sampai sore hari. Guru melakukan kerjasama dengan orangtua diawal pembelajaran, orang tua diijinkan menemani anak sampai mereka punya teman sehingga berani untuk ditinggal di sekolah. Disamping itu juga menggunakan pendekatan kepada anak belajar dengan duduk dengan anak dengan pendekatan ini muncul keberanian. Kontrol dalam pembelajaran kalau anak melakukan kesalahan guru tidak menghukum namun meminta membaca istigfar dan siswa pun sudah diam sendiri. Pada peserta didik yang duduk di kelas satu, tidak diberikan pekerjaan rumah sehingga ketika tiba di rumah bisa istirahat ataupun bermain.

Hasil wawancara kepada Bapak Kosasih Wali Kelas 4 juga tidak jauh berbeda. Guru berkumpul dan membicarakan dokumen-dokumen apa saja yang akan digunakan untuk satu tahun ke depan. Setelah itu guru membuat dan mempersiapkan Prota (program tahunan), Prosem (program semester), silabus, dan RPP. Dari RPP inilah guru dapat memperkecil atau memfokuskan materi. Ketika ingin melaksanakan proses pembelajaran, guru harus membaca lagi silabus dan RPP. Berdasarkan RPP inilah guru dapat menyiapkan buku pelajaran yang berkaitan dengan materi yang diajarkan di kelas. Pola pembelajaran yang dilakukan yaitu pembelajaran bersifat tematik, yaitu pembelajaran yang diawali dengan suatu tema tertentu yang mengaitkan dengan pokok bahasan lain, konsep tertentu dikaitkan dengan konsep lain yang dilakukan secara spontan atau direncanakan baik dalam satu bidang studi atau lebih dan dengan beragam pengalaman belajar sehingga pembelajaran menjadi semakin bermakna Subroto dalam (RAGA \& KEBUMEN, n.d.). Sejalan dengan pendapat sebelumnya, Prabowo dalam (Kunarto, 2019) menyatakan bahwa pembelajaran tematik/terpadu adalah suatu proses pembelajaran dengan melibatkan atau mengkaitkan berbagai bidang studi. Pembelajaran terpadu, merupakan pendekatan belajar mengajar yang memperhatikan dan menyesuaikan dengan tingkat perkembangan anak didik. Kemudian pembelajaran tematik dipadukan atau dikaitkan dengan ilmu agama seperti hadis dan doa-doa. Pembelajaran tematik ini telah terstruktur dari jadwal sekolah, sehingga dari kelas satu sampai kelas enam sudah mempunyai jadwal tersendiri. Dalam pembagian tempat kegiatan pembelajaran telah terbagi misalnya apabila kelas satu sampai kelas tiga (kelas rendah) sedang belajar ilmu keagamaan, maka kelas empat sampai kelas enam (kelas tinggi) belajar pembelajaran umum. Tempat proses pembelajaran dilakukan di mana saja, yaitu bisa di masjid, di teras depan kelas, di halaman, dan bahkan di ruang kepala sekolah. Ada juga pembelajaran khusus yaitu pembelajaran tentang aktivitas sehari-hari seperti siswa kelas rendah mendapat pembelajaran dasar tentang cara mengikat tali sepatu, melipat pakaian, sedangkan di kelas tingi mendapat pembelajaran tentang menyiang ikan dan menyetrika pakaian. Dalam pelaksanaan pembelajaran, guru selalu mengaitkan materi pembelajaran umum dengan hadist dan doa-doa. 
Pembelajaran ini ditunjang dengan metode yang bervariasi. Penentuan penggunaan metode disesuaikan dengan materi yang akan diajarakan. Metode yang sering digunakan antara lain; metode bermain, diskusi, demonstrasi dan belajar di lapangan atau di luar kelas. Ada juga penerapan metode ceramah. Walaupun menggunakan metode ceramah, siswa juga dituntut aktif. Seperti yang diketahui, banyak anggapan bahwa metode ceramah itu hanya gurunya saja yang aktif, sedangkan peserta didiknya pasif. Hal inilah yang menjadi pendorong bagi guru untuk mengubah bahwa metode ceramah itu tidak hanya gurunya saja yang aktif, melainkan siswanya juga. Cara untuk mengaktifkan peserta didik ketika guru menggunakan metode ceramah yaitu guru tidak hanya sekadar menjelaskan tetapi juga diselingi dengan pancingan-pancingan guru seperti memberi pertanyaan-pertanyaan yang dapat dijawab secara lisan maupun tulisan. Peserta didik yang menjawab secara lisan dapat langsung menjawab dari tempat duduknya, sedangkan peserta didik yang menjawab secara tertulis dapat dilakukan di depan kelas, yaitu peserta didik menulis di papan tulis. Tidak cukup seperti itu, setelah salah satu peserta didik menjawab pertanyaan guru, guru dapat memberikan pertanyaan lagi kepada peserta didik yang lain dengan soal yang sama seperti sebelumnya atau soal baru, atau juga dengan bertanya untuk menegaskan jawaban yang telah dijawab oleh peserta didik sebelumnya.

Penerapan metode yang bervariasi ini terkadang tidak berjalan mulus Ada beberapa hambatan yang sering dialami guru dalam menerapkan metode pembelajaran, yaitu pertama membina anak untuk tertib. Hambatan ini terjadi ketika peserta didik diberi benda atau suatu media yang menarik, peserta didik dengan antusias mengemukakan pendapatnya. Hal ini sangat bagus membuat peserta didik aktif tetapi kebanyakan peserta didik tidak terkontrol sehingga suasana kelas menjadi gaduh. Kedua, susah bergerak cepat. Hambatan ini dijumpai apabila ada kegiatan pembelajaran dilakukan di luar kelas. Membimbing peserta didik untuk ke luar kelas tidak mudah. Ada peserta didik yang lama sampai ke lokasi belajar yang telah ditentukan dan ada juga yang sambil bermain-main sehingga lama ke lokasi belajar tersebut. Begitu juga waktu kembali ke kelas. Hal inilah yang dapat menghabiskan waktu belajar yang cukup banyak.

Untuk mengatasi hambatan tersebut, cara guru mengingatkan peserta didik, menasehati yang dikaitkan dengan hadis-hadis dan selalu memberikan hal yang positif terhadap peserta didik sehingga antusiasme peserta didik tidak berubah menjadi rasa takut. Guru lebih memperketat pengkontrolan agar peserta didik menjadi tertib dan bisa bergantian dalam berbicara. Dalam berbicara ada proses interaksi sehingga peserta didik diberi pemahaman agar dapat bergantian dalam berbicara. Apabila ada yang berbicara maka yang lain mendengar.

Agar siswa berperan aktif Bapak Kosasih menerapkan prinsip bahwa guru harus lebih aktif, baik aktif lisan maupun aktif pandangan. Jika gurunya aktif , maka peserta didik dapat ikut aktif. Caranya guru melakukan aktif lisan yaitu guru selalu memberi pertanyaan-pertanyaan kepada peserta didik. Melalui pertanyaan-pertanyaan inilah secara tidak sadar membuat peserta didik menjadi aktif dalam berbicara dan aktif dalam menyimak. Aktif berbicara, peserta didik merespon pertanyaan yang diajukan oleh guru. Aktif menyimak, apabila ada peserta didik kurang tepat menjawab pertanyaan dari guru, maka peserta didik yang menyimak dapat membenarkan jawaban yang kurang tepat tersebut. apabila ada peserta didik yang tidak aktif berbicara dan menyimak, maka guru harus aktif dalam pandangan. Maksudnya, guru melihat mana peserta didik yang hanya berdiam diri atau ada peserta didik yang mengantuk. Guru dapat memberikan pertanyaan agar konsentrasi peserta didik tersebut kembali. Selain menjawab secara lisan, peserta didik dapat menjawab secara tertulis, yaitu menulis di papan tulis.

Penggunaan media disesuaikan dengan materi pelajaran, Menurut Bapak Kosasih, jika menggunakan media peserta didik lebih aktif, sehingga memacu guru untuk lebih aktif. Peserta didik yang aktif membuat guru menjadi semangat dan menimbulkan suasana kelas yang menyenangkan. Apabila tidak menggunakan media, guru harus aktif agar dapat membuat peserta didik juga ikut aktif. Peserta didik pun banyak yang bingung jika hanya mendengar penjelasan guru dan hanya melihat buku paket yang digunakan pada proses pembelajaran. Untuk itu pembelajaran di kelas IV menggunakan media seperti media gambar, audio, dan infokus.

\section{Kesimpulan}

Pola pembelajaran adalah hal yang sangat berpengaruh dalam proses pembelajaran di kelas yang selanjutnya akan mempengaruhi penerimaan informasi serta pengalaman oleh peserta didik. Keaktifan di kelas adalah kunci utama. Keaktifan ini harus menyangkut guru dan peserta didik. Apabila salah satu saja yang aktif maka pembelajaran di kelas akan kurang maksimal baik dari penyampaian ataupun penerimaan informasi. Berbagai metode dan media pembelajaran digunakan untuk membantu proses pembelajaran. Selain itu perlu diselingi dengan penjelasan mengenai hadis-hadis dan ayat-ayat Al-Qur'an yang dihubungkan dengan sesuatu yang terjadi di kelas maupun di luar kelas. Hal ini guna menanamkan nilai- 
nilai pada diri peserta didik. Memang segala sesuatu tidak bisa berjalan sesuai dengan yang diinginkan, akan tetapi bisa diusahakan agar seperti yang diinginkan. Seperti contoh peserta didik yang sulit dikontrol ketika proses pembelajaran di luar kelas. Hal ini bisa menjadi peluang bagi guru untuk lebih menanamkan nilai pada diri peserta didik.

\section{Daftar Pustaka}

Danim, S. (2010). Perkembangan peserta didik. Bandung: Alfabeta.

Kunarto, K. (2019). UPAYA MENINGKATKAN MOTIVASI DAN HASIL BELAJAR IPA MELALUI PENERAPAN MODEL PEMBELAJARAN NUMBERED HEADS TOGETHER BERBANTU MEDIA VIDEO. ELEMENTARY SCHOOL (Jurnal Pendidikan Dan Pembelajaran Ke-SD-An, 6(1).

Marganingsih, A., Pelipa, E. D., \& Erwin, E. (2019). ANALISIS ENTREPRENEUR LIFE SKILLS MAHASISWA PROGRAM STUDI PENDIDIKAN EKONOMI DI STKIP PERSADA KHATULISTIWA SINTANG. JURKAMI: Jurnal Pendidikan Ekonomi, 4(2), 99-110.

Mawardi, I. (2012). Pendidikan Life Skills Berbasis Budaya Nilai-nilai Islami dalam Pembelajaran. Nadwa, 6(2), 215-230.

Nasional, D. P. (2015). Kamus Besar Bahasa Indonesia (KBBI) Online. Tersedia Dalam: Http://Kbbi. Web. Id/. Diakses, 4.

Normawati, F. (2016). MENINGKATKAN KEAKTIFAN PESERTA DIDIK DALAM PROSES PEMBELAJARAN DENGAN MENGGUNAKAN MODEL PEMBELAJARAN MAKE A MATCH (MEMBUAT PASANGAN). FKIP UNPAS.

Qutub, S. (2011). Sumber-Sumber IImu Pengetahuan dalam Al Qur'an dan Hadits. Humaniora, 2(2), 1339-1350.

RAGA, D. P. P. D. A. N. O., \& KEBUMEN, P. (n.d.). PELATIHAN KURIKULUM 2013 PADA TINGKAT SEKOLAH DASAR DI UPT.

Sugiyono, P. (2015). Metode penelitian kombinasi (mixed methods). Bandung: Alfabeta.

Sukmadinata, N. (n.d.). S.(2011). Metode Penelitian Pendidikan. 